\title{
Editorial: Ageing \& Society in eight parts
}

This issue marks another step in the development of Ageing \& Society, being the first of eight to be published this year. The last expansion was from four to six annual issues in I996. The volume's pages will be expanded to over I,200, and the number of published main papers will rise from around 43 to around 57. Another change recently occurred: late in 2007 the journal adopted the electronic submission and management of papers on the Manuscript Central platform. I should emphasise, however, that the aims, ambitions and ethos of the journal are as before; they have not changed since the foundation of the title. ${ }^{1}$ The expansion is in line with the strong worldwide expansion of journals' publication that is being driven by the increased usage enabled by electronic publication and university intranets. The numbers are colossal. Since 2003, Cambridge University Press have published over 4,000 online issues with I90,000 articles (or maybe publication items) that users have accessed through nearly ig million downloads. In the United Kingdom in 2004-05, higher education libraries' serials subscriptions had climbed to a record I.2 million, more than double the number io years before. 'Over that period, the ratio of books to journals spending shifted from $45: 55$ to $34: 66{ }^{\prime} .^{2}$ Print-only subscriptions were 26 per cent of all subscriptions in $2004^{-0}$, down from 47 per cent in 200I-02. There have been similar trends worldwide. Fourteen Canadian university libraries and 99 in the United States belong to the Association of Research Libraries; in 2004-05, around 50 per cent of their journals expenditure was for electronic subscriptions, compared to $27 \mathrm{per}$ cent in 200I-02.

Ageing E' Society's expansion also reflects the transformation of interest in applied gerontology from a rare academic enthusiasm to an active pursuit of policy makers and several professions in ever more countries. That has supported the growth of gerontology in university curricula and the mushrooming of researchers and, as a consequence, the proliferation of new journals. As late as 1959, only two English-language journals with gerontology or ag(e)ing in the title had been founded, and during the ig6os only three more began. Then 30 new titles were founded during the I97os and I980s, and 20 more during the ig9os. That number looks likely to be exceeded during the present decade. ${ }^{3}$ It is also the case that Ageing E्S Society is doing comparatively well. According to the ISI Web of Knowledge citation metrics, it is in the top three international journals in social gerontology, and in 2006 ranked ninth among gerontology and geriatrics journals in the 
(English-communicating) world, up from eleventh in 2005. The journal's impact factor rose from 0.7I in 2004, through 0.95 in 2005, to I.49 in 2006. The rise from 2006 to $2007(57 \%)$ was above the average for Cambridge journals $(\mathrm{I} 3.2 \%){ }^{4}$

The number of submitted papers continues to grow, and will be around I6o in 2007 , compared to I25 in 2005. It is most welcome that the journal again receives substantial papers in psychology, and that applied economists submit their work. The nationality of authors continues to diversify, but there are still few papers from Africa, Latin America and Eastern Europe, and none from India and China. In short, even allowing for the bias of an English-language lens, gerontology is still a pursuit of the advantaged nations of the world. We know precious little of the welfare of older people in the poorest and most rapidly transforming world regions. The progress of the journal as ever depends on the patient and tenacious efforts of the authors, the editorial team and the production staff, and the selfless contributions of a large electronic college of reviewers. These efforts are developing well-grounded evidence and understanding of the circumstances of older people in many varied settings. All gerontologists are occasionally dismayed by displays of ignorance and false assumptions about older people and the implications of population ageing, but changes for the better in general understanding can be discerned. If in even small ways gerontology research and writing educates policy makers and care professionals towards a better understanding of older people's circumstances, and if it helps bolster the regard and self-image of those who are sick and frail, the communication of solid gerontological understanding has inestimable value.

\section{NOTES}

I They were amply reviewed in a previous editorial: see Warnes, A. M. 2002. Editorial: Ageing $\mathcal{E}^{2}$ Society in its majority. Ageing $\mathcal{E}^{2}$ Society, 22, I, 3-6.

2 Sowden, P. 2007. University Library Spending on Books, fournals and Electronic Resources: 2007 Update. Publishers Association, London, 4. Other cited statistics are from this publication. I am grateful to Patrick McCartan and Adrian Porter of CUP Journals for drawing my attention to this source.

3 For more details see Warnes, A. M. and Phillips, J. 2007. Progress in gerontology: where are we going now? In Bernard, M. and Scharf, T. (eds), Critical Perspectives on Ageing Societies, Policy, Bristol, I39-54.

4 To put the increase in perspective, the impact factor of the Fournal of Modern Asian Studies rose by 140 per cent between 2006 and 2007.

\section{TONY WARNES}

